DOI: https://doi.org/10.34069/AI/2021.43.07.8

How to Cite:

Veas Iniesta, D.S., \& Estay Sepúlveda, J.G. (2021). Development of methods and tools of the commercialization of high-tech projects on the example of Moscow Aviation Institute (National Research University). Amazonia Investiga, 10(43), 83-95. https://doi.org/10.34069/AI/2021.43.07.8

\title{
Development of methods and tools of the commercialization of high-tech projects on the example of Moscow Aviation Institute (National Research University)
}

\section{Разработка методов и инструментов коммерциализации высокотехнологичных проектов на примере Московского авиационного института (национального исследовательского университета)}

\begin{abstract}
Building an economy with a reduction in the innovation cycle, i.e. in complex of works, which includes the stages and results of the innovation process, now is one of the main features of the modern development of the world economy. This is a new stage in the formation of an innovative society. One of the key tasks of the state Customer of the program, the Ministry of Science and Higher Education, is to obtain the final product as a result of applied scientific research and experimental development.

The article discusses the toolkit for management monitoring of the commercialization of hightech projects, which is relevant at the moment. The necessity of introducing innovations in the field of control over the fulfillment of obligations under scientific and technical projects has been substantiated.
\end{abstract}

Keywords: Federal Target Program, industrial partner, priority areas, commercialization, hightech project.

\begin{abstract}
Аннотация
Построение экономики с сокращением инновационного цикла, т.е. комплекса работ, который включает в себя этапы и результаты инновационного процесса, на данный момент времени является одной из основных черт современного развития мирового хозяйства. Это новый этап формирования инновационного общества. Одной из ключевых задач Государственного заказчика Программы, Министерства науки и высшего образования, является получение конечного продукта в результате прикладных научных исследований и экспериментальных разработок.

В статье рассматривается инструментарий управленческого мониторинга коммерциализации выскокотехнологических проектов, который актуален в текущий момент. Обоснована необходимость внедрения нововведений в области контроля за исполнения обязательтств исполнителей по научно-тахническим проектам.
\end{abstract}

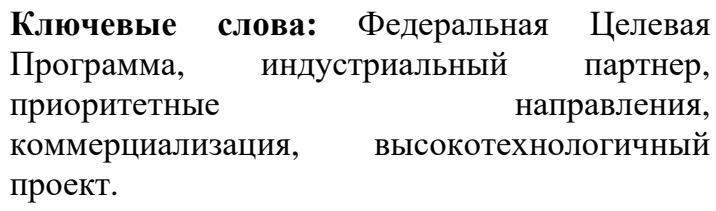

\footnotetext{
${ }^{27}$ Senior Lecturer, Moscow Aviation Institute (National Research University), Moscow, Russia.

${ }^{28}$ Universidad Adventista de Chile, Chile. Universidad de Salamanca, España. Universidad Católica de Temuco, Chile.
} 


\section{Introduction}

According to the Federal Target Program (it is a set of measures in Russia that ensure the effective solution of tasks that require state support, linked by resources, performers and deadlines for implementation) "Research and development in priority areas of development of the scientific and technological complex of Russia for 20142020" (FTP) (Resolution of the Government of the Russian Federation № 426, 2013), as well as Resolution № 218 (possibility of allocating subsidies to manufacturing enterprises for a period of 1 to 3 years, with a financing volume of up to 100 million rubles per year to finance complex projects of organizing high-tech production carried out jointly by manufacturing enterprises and higher educational institutions or scientific institutions) "On measures of state support for the development of cooperation of Russian educational institutions of higher education, state scientific institutions and organizations implementing complex projects for the creation of high-tech production, within the framework of the subprogram "Institutional development of the research sector" of the state program of the Russian Federation "Development of science and technology" for 2013 - 2020" (Resolution № 218) priority areas for the development of science and technology and technology in the Russian Federation are the following (Resolution of the Government of the Russian Federation № 218, 2010):

- $\quad$ security and countering terrorism;

- life sciences;

- industry of nanosystems;

- information and telecommunication systems;

- rational nature management;

- energy efficiency, energy conservation and nuclear energy;

- $\quad$ transport and space systems;

- $\quad$ promising types of weapons, military and special equipment;

- $\quad$ energy efficiency;

- $\quad$ energy saving;

- nuclear energy.

Now, the total amount of financing is about 180 000 million rubles, including 150000 million rubles of the federal budget. Based on the foregoing, it can be concluded that the result obtained is necessary for further commercialization in order to obtain additional funds through its sale, thereby returning the funds spent to the state through taxes and fees (Dmitriev \& Novikov, 2021). The Figure 1 shows the life cycle of the return of received subsidies through the commercialization of the final product (Lastochkina \& Savilova, 2020).

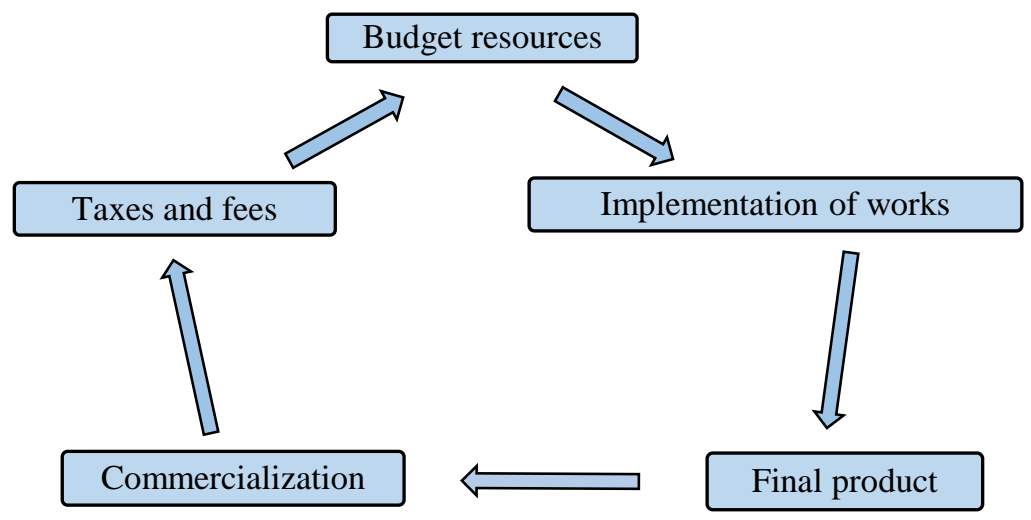

Figure 1. Life cycle of the return of received subsidies through the commercialization of the final product The relevance of the study is due to the need for a comprehensive, coordinated by industry and priority areas of development, solutions to the problem of developing tools for the commercialization of high-tech projects (both final product and its components) (Beilin et al., 2019; Burdina \& Bondarenko, 2020).

Accordingly, the following categories of performers are primarily interested in introducing innovations in this area (Putyatina et al., 2020; Tikhonov, 2021):
- Russian higher educational institutions, developing not only educational activities, but also scientific ones;

- manufacturing enterprises that use universities for the development of high- 


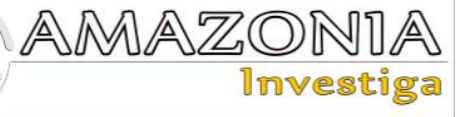

tech production, as well as stimulating innovation in the Russian economy.

These persons have objective and subjective interests. From their part, there is a demand for the existence and functioning of a highly effective management monitoring toolkit for the commercialization of projects in the modern high-tech production market. This implies not only the existence of a solution to the problem, but also the implementation of measures to implement the appropriate tools. The state is also interested in the transparency and predictability of the results of the commercialization of projects and subsidies, since they are carried out from the federal budget. Successful implementation of the planned indicators of projects contributes to a change in the structure of the economy and its transition to a model of sustainable innovative development (Arsenieva et al., 2020).

The article describes in detail the current situation in the field of interaction between Russian high-tech enterprises, universities and the state. For a comprehensive understanding of the processes and methods of interactions between the above subjects, a comprehensive quantitative and qualitative description of works and projects financed from the federal budget is given. The strengths and weaknesses of the projects are considered, and statistical data are provided.

After studying the mechanisms of the projects, a methodological and structural description of the prerequisites for the occurrence of a lag from the planned indicators is given. The existing tools for monitoring the implementation of commercialization indicators are considered in detail. The research is supported by statistical data from various projects.

As a result, the paper describes measures and proposals for the improvement of existing tools and forms of management monitoring of the commercialization of projects to create products of high-tech enterprises. A practical example of the implementation of the proposed toolkit in the work of one of the departments of Moscow Aviation Institute (National Research University) is given.

\section{Theoretical Basis}

The complexity of the consideration of the problem under study and the degree of elaboration of the research topic is due to the versatility of the theoretical directions of this research. A significant contribution to the field of commercialization was made by the works of Dubitskaya, E., Tcukanova, O. (2018), Ziyadin, S., Omarova, A., Doszhan, R., Saparova, G., \& Zharaskyzy, G. (2018), Pinkovetskaia, I. S., Arbeláez-Campillo, D. F., Rojas-Bahamón, M. J., Novikov, S. V., \& Veas Iniesta, D. S. (2020a), Ling, J. (2020), etc. Their works that have a fundamental focus and provide a starting point for further research in this area, however, the problem of commercializing of high-tech projects (both final product and its components) remains unresolved: there is a lack of data assumed by the contract or agreement for five years after the end of work on the volume of high-tech products developed within the framework of the project (Verevka, 2018; Audretsch \& Belitski, 2020).

Thus, on the one hand, there is a demand for the development of appropriate tools, and on the other hand, at the moment there is no correct solution for its implementation. Accordingly, the problems of this study are relevant (Chaika, 2019; Chaika, 2021).

The information base of the study is various scientific studies of Russian and foreign scientists, statistical data of the Ministry of Science and Higher Education, factual data of project participants, as well as internal documents of departments of Moscow Aviation Institute, namely the Scientific Center of Special Radio-Electronic Systems and Management (SC SRESM) (Resolution of the Government of the Russian Federation № 218, 2010; Resolution of the Government of the Russian Federation № 426, 2013).

\section{Methodology}

The aim of the study is to develop the main components of the management monitoring toolkit for the commercialization of high-tech projects in relation to modern Russian conditions.

To achieve the above goal of research work, the following scientific and applied scientific tasks were formulated and subsequently solved:

1. to rely the data on the current state of implementation of high-tech projects, to identify factors that affect the prospects for the development of commercialization of both the final product and its components;

2. to identify the fundamental feasibility of introducing special innovations in terms of developing tools for management 
monitoring of the commercialization of high-tech projects;

3. to formulate requirements for a specialized mechanism and to define the conceptual principles of its functioning;

4. to develop a scheme for commercialization tools in priority areas of development;

5. to test the developed toolkit on the example of a specific scientific and technical project to substantiate its practical feasibility and effectiveness;

6. to assess the expected economic efficiency of the implementation of the developed management monitoring toolkit for the main categories of persons who have objective and subjective interests.

The object of the research is Russian universities, manufacturing enterprises and jointly produced products within the framework of project implementation.

The subject of the research is the relations arising in the process of creating high-tech production of new products and during the created (developed) high-tech products.

Scientific research tools and its theoretical basis is a set of theoretical constructions, including the following: innovation, innovative business, scientific activity, technology commercialization, research and development work, applied jurisprudence, organizational design theory, etc.

The scientific novelty of the research results lies in the conceptualization and instrumentalization of the commercialization of the result of the work of scientific and technical projects.

In terms of results, this novelty is:

1. in the argumentation of the expediency of introducing special innovations in terms of developing tools for management monitoring of the commercialization of high-tech projects;

2. in identifying the critical need to improve the mechanism of commercialization of both final product and its components;

3 . in multidimensionality of the expected economic efficiency of the development implementation based on the results of the current research.

Scientific results are positioned according to the following headings of the passport of the specialty 08.00.05 "Economics and management of the national economy (by industry)":
- $\quad$ Development of new and adaptation of existing methods, mechanisms and tools for the functioning of the economy, organization and management of economic entities in industry";

- $\quad$ "Formation of mechanisms for sustainable development of the economy of industrial sectors, complexes, enterprises";

- $\quad$ Instruments for intra-firm and strategic planning at industrial enterprises, industries and complexes";

- "Theoretical and methodological foundations for monitoring the development of economic systems of the national economy".

The theoretical significance of the study lies in the contribution to the progress of the theoretical base of technically complex goods and services, for the production of which complex technological processes are used with the planned positive economic effect of the sale of goods, works, services (in comparison with existing analogues) at the stages of the product life cycle (Pinkovetskaia et al., 2020b).

The practical value of the results of research work can be determined by the benefits of introducing applied research and experimental work into the implementation process, as well as research and development work in terms of commercializing the results and, thereby, returning budget funding through taxes and fees.

Approbation of research results. The main direction of the dissertation was reported, discussed and approved at some conferences and seminars. The research results will be implemented in Moscow Aviation Institute (National Research University).

In the process of carrying out the work, the following research methods were used and involved (steps that were necessary to achieve the goal):

- empirical (study of information sources, analysis of information received, observation, experiment);

- theoretical (analysis, synthesis, classification, deduction, induction);

- $\quad$ quantitative (statistics);

- $\quad$ high quality (interviews, discussions).

\section{Discussion}

Over the past several years, work has been carried out within the framework of FTP, the state Customer of which is the Ministry of Science and Higher Education of the Russian 


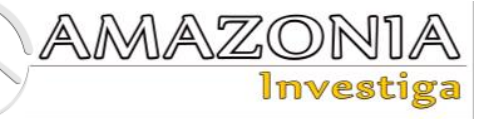

Federation in order to form a competitive and efficiently functioning sector of applied research and development. It provides subsidies from the federal budget for financial support (reimbursement) of costs associated with the performance of work in accordance with the developed terms of reference, composition and terms specified in the schedule (Dmitriev, 2020; Tikhonov \& Zelentsova, 2021). The recipient of the subsidy is obliged to perform work in accordance with the terms of the agreement with

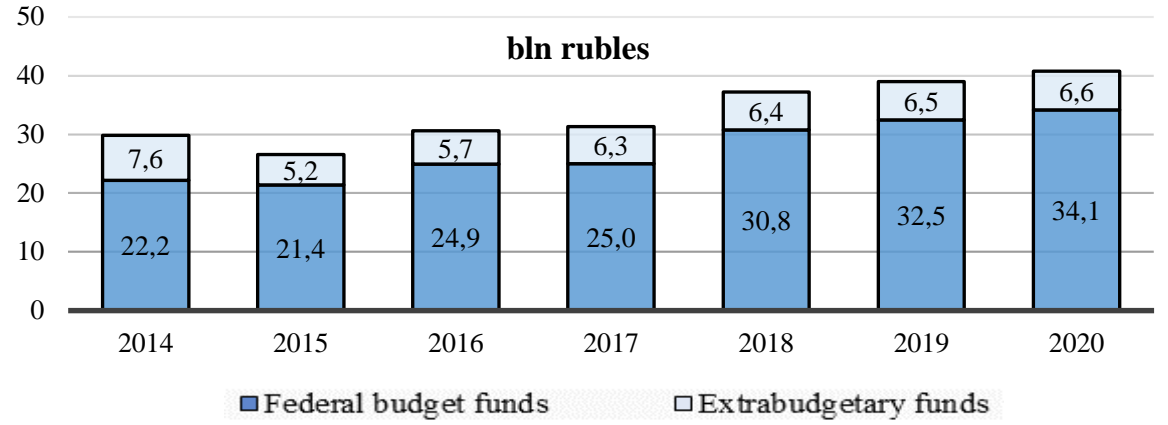

Figure 2. Volume of FTP funding from 2014 to 2020

Source: authors

The results and indicators of socio-economic efficiency were the following:

- creation of a basis for changing the structure of the Russian economy for its transition to a model of sustainable innovative development;

- formation of scientific and technical potential in priority areas of development;

- increasing the number of innovatively active enterprises and organizations by demonstrating the economic effect from the implementation of the program;

- realization of the potential of Russian science;

- developed new technological (technical) solutions and results of intellectual activity obtained by using the properties and (or) features of functioning and (or) application using the created layouts, models, experimental samples and (or) prototypes;

- developed drafts of technical specifications for subsequent development (experimental and technological) work to create new types of products and technologies.

Now, the program continues to be implemented, $96 \%$ of projects that were supposed to be completed have received the planned results. However, a much lower percentage can be shown in relation to the commercialization of developments. This is happening, among other things, due to a deficit of finance, changes in the the Ministry of Education and Science and transfer the results of scientific and technical activities created at the expense of the subsidy funds to an industrial partner (enterprise in which resources are combined into a production process for the purpose of producing products or providing services) for commercialization of the results of work on the territory of the Russian Federation. The Figure 2 shows the volume of FTP funding from 2014 to 2020. 
Interindustry Analytical Center LLC (IAC LLC) in the first quarter of 2019 monitored the implementation of 58 projects of 1-5 and 7 stages of implementation of Resolution 218, accompanied by it, sales obligations received in within the framework of the work performed on the projects of $R \& D$ results.

Since the agreement on the conditions for the provision and use of subsidies does not directly provide for the submission of information on sales to the Ministry of Education and Science twice a year, the recipient organizations consider January as the main term for the sales report, thus, having the opportunity to cover the entire past year to summarize and present the report. In this regard, in the third quarter of 2018, certificates in Form 1.5 for projects that have passed to the stage of commercialization were not provided.

As of the time of the study, on some of the projects, reports on high-tech products created (developed) within the framework of the integrated project, on the progress of the integrated project and the volume of products for the second half of 2017 were not submitted.

As a result, in accordance with the reports submitted by the recipient organizations on hightech products created (developed) within the framework of the integrated project, on the progress of the integrated project and the volume of products manufactured in 2018, the volume of manufactured products amounted to about 50 billion rubles. Total volume of products manufactured for all projects for the period of 2013-2018 exceeded 211 billion rubles.

Due to the failure to provide sales certificates for more than $80 \%$ of projects, it is difficult to estimate the actual total fulfillment of sales obligations.

At the same time, it is possible to single out only three projects for which the obligations to implement the results, their commercialization and sales are being fulfilled, one project with a slight lag behind the planned sales volume fulfills the organization's project obligations and three projects with a lag of more than $20 \%$.

Based on the data presented for projects of the first and second stages, it follows that for the reporting period 2013-2017, the volume of products manufactured for 23 projects amounted to 80353.4 million rubles (or $30 \%$ of the declared volume).
There are many factors, that are reasons for the admitted lag from the planned sales volumes:

1. the most significant influence on the success of the commercialization of the results obtained is provided by market and marketing factors. Possible drop in demand for products developed and created within the framework of projects. At the time of submission of applications for Resolution № 218 competition, industrial organizations were assessing the market, carrying out marketing research and developing strategies for promoting the products being created. However, in the course of the work on the projects, the market situation changed, substitute products appeared, competitors used aggressive marketing, potential consumer changed goals, objectives and methods of achieving them, and cheaper substitutes for the developed products appeared. Thus, the emergence of competitors and likely decrease in the demand for the product by the target audience are strong factors influencing the commercialization of products. The risk of copying the development by competitors, the appearance on the market of an analogue (substitute product) can be leveled through patent protection of the product. Marketing risks can be associated with incorrectly chosen product offer, pricing method or chosen marketing strategy (strategy for promoting a product to the market);

2. the next important factor influencing the success of commercialization is financial one (economic (financial) situation of the organization or in the country as a whole). The fluctuation of the ruble exchange rate, which in turn affects the possibilities (limitations) of purchasing materials, components and equipment to ensure a continuous production process and the operability of production facilities, reduces the volume of products. In addition, there may be risks associated with raising funds at the stage of commercialization. These risks are associated with possibly higher funding needs than planned by the project, as well as the need to find new sources of funding. Particularly acute for Russia, the process of successful commercialization may be influenced by the imposed sanctions: restrictions on the purchase of materials, components and equipment to ensure a continuous production process and the operability of production facilities and reducing the volume of products; 


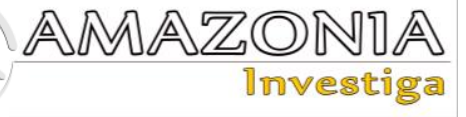

3. production, technological and staff risks often arise in commercial structures and at enterprises of the industrial complex. The highest among these risks is the risk of noncompliance with production regulations. There is also a risk of product quality deterioration;

4. organizational and partner factors can play an important role in achieving success at the stage of commercialization. To reduce the dependence on one supplier or consumer, it is necessary to clearly plan the timing of the project and ensure a careful selection of intermediary partners.

All the indicated factors (risks) have a significant impact on the decrease in sales volumes for projects. The negative impact of these reasons can be avoided (or at least reduced) by revising the criteria for the competitive selection of projects for the provision of subsidies.

The Figure 3 shows some of the survey externalities that have influenced the commercialization process.

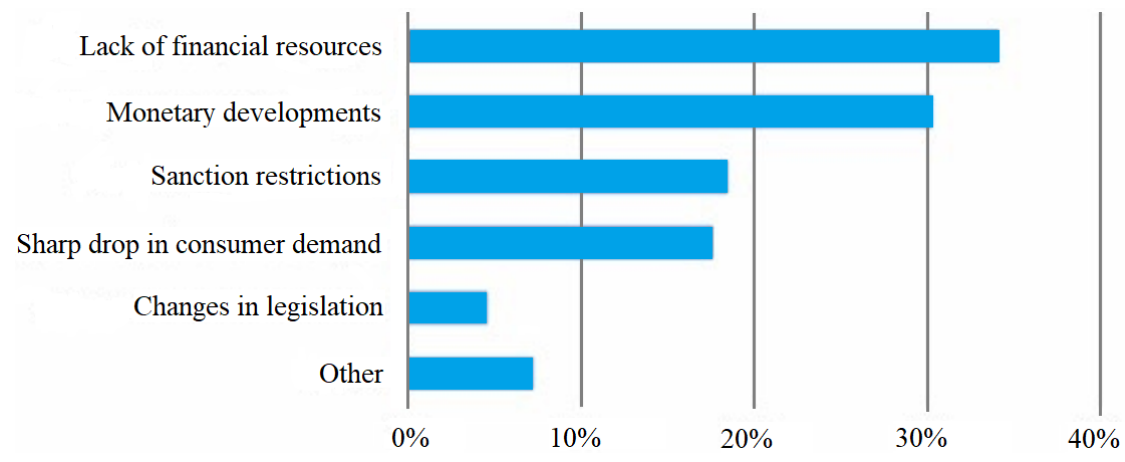

Figure 3. Survey externalities influenced the commercialization process.

The main form of commercialization of results is the conclusion of a license agreement with an industrial partner as a means of "disposing of the exclusive right" to use the result of intellectual activity. With an increase in the number of concluded license agreements, the volume of research results obtained, accepted for further implementation, increases. However, the prospects for further implementation can be described as uncertain ones.

An analysis of the reporting documentation posted on the official website of the System of Expertise (sstp.ru) shows that in many completed projects there are no specific plans or strategy for using the results obtained and their further commercialization. In most cases, this is referred to as a medium-term forecast. There is an inclusion in the tender documentation of information about the qualifications and resources of the industrial partner, as well as a report on marketing research, which currently needs to be prepared only at the last stages of the project.

Based on the analysis of the theory and practice in the field of management monitoring of the commercialization of high-tech projects, a toolkit was proposed in the work that allows to significantly increase the number of projects that have switched to commercialization, that is, to the process of developing and implementing a number of activities with the help of which the results of work can be offered on the market with commercial purposes. It is based on the assumption that the following factors are the key factors affecting the level of the above problem (at the stage of applying for participation in the project):

- lack of a strategy and plan for commercialization;

- lack of information about the qualifications and resources of the industrial partner;

- lack of marketing research report agreed by both parties: the recipient of the subsidy and the industrial partner;

- lack of plan for the volume of production, limited in time;

- absence of penalties.

However, the increased attention to the problem of commercialization, nevertheless, should not turn this criterion into the main one in the competitive selection of projects during the implementation of the program in the priority areas of science and technology development.

In order to get acquainted with the results of the transition of projects to the stage of commercialization, representatives of IAC LLC are invited to carry out monitoring visits to the 
industrial sites of enterprises that have completed R\&D under contracts and have begun to manufacture and sell products developed using the results of the project. In the second quarter of 2019, IAC LLC is proposed to form a work plan with the recipients of subsidies for projects that have entered the stage of commercializing the results obtained, and as part of the further implementation of this plan, assess the achievement of requirements and develop a number of measures that will include monitoring visits with checking the current status work on projects, primarily those where there is nonfulfillment and there has been a backlog.

In accordance with the agreement on the provision of the subsidy, within five years after the end of its validity, the recipient of the subsidy is obliged to provide the Ministry of Education and Science with information on high-tech products created (developed) within the framework of the integrated project, on the progress of the integrated project and the volume of products in the Form of 1.5, shown in the Figure 4. However, after the end of the contract, there is no strict control over the work of the recipients of the subsidy, which leads to delays in the provision of data. The lack of a predetermined specific reporting period makes it difficult to collect reliable information. Recipient organizations consider January as the conditional month for submitting this report, however, practice shows that in $80 \%$ of cases the information is not provided.

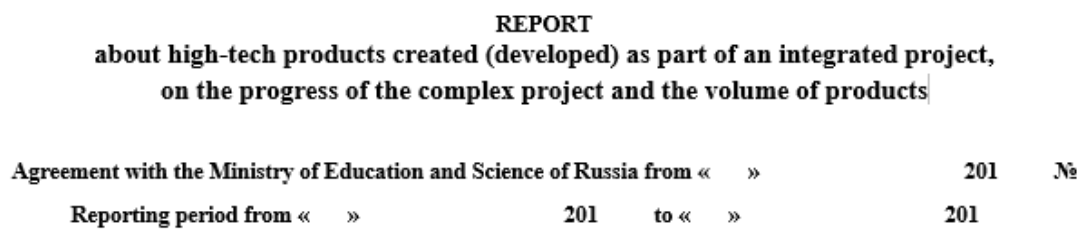

1 Volumes of manufactured high-tech products

\begin{tabular}{|c|c|c|c|c|c|c|c|c|c|c|c|c|c|c|}
\hline \multirow{3}{*}{$\mathrm{Ne}$} & \multirow{3}{*}{$\begin{array}{l}\text { Product name } \\
\text { (new and im- } \\
\text { proved } \\
\text { high-tech prod- } \\
\text { ucts / technol- } \\
\text { ogy) }\end{array}$} & \multirow{3}{*}{$\begin{array}{l}\text { Name and } \\
\text { location of } \\
\text { the manu- } \\
\text { facturing } \\
\text { company }\end{array}$} & \multirow{3}{*}{$\begin{array}{l}\text { Document desig- } \\
\text { nation (No. TC } \\
\text { or set of design } \\
\text { (technological) } \\
\text { documentation) }\end{array}$} & \multicolumn{6}{|c|}{ Delivery contract } & \multicolumn{5}{|c|}{ Proof of delivery } \\
\hline & & & & \multicolumn{3}{|c|}{ Buyer's brand name, country } & \multirow{2}{*}{$\begin{array}{l}\text { Date of } \\
\text { conclusion }\end{array}$} & \multirow[b]{2}{*}{ Number } & \multirow{2}{*}{$\begin{array}{c}\text { Number } \\
\text { of } \\
\text { delivery } \\
\text { units }\end{array}$} & \multirow[b]{2}{*}{ Name } & \multirow[b]{2}{*}{ Date } & \multirow[b]{2}{*}{ Number } & \multirow{2}{*}{$\begin{array}{l}\text { Number of } \\
\text { products } \\
\text { (batch size) }\end{array}$} & \multirow{2}{*}{$\begin{array}{l}\text { Amount, } \\
\text { million } \\
\text { rubles }\end{array}$} \\
\hline & & & & $\begin{array}{c}\text { Domestic } \\
\text { market }\end{array}$ & $\begin{array}{c}\text { CIS } \\
\text { countries }\end{array}$ & $\begin{array}{c}\text { Other } \\
\text { foreign } \\
\text { countries }\end{array}$ & & & & & & & & \\
\hline \multicolumn{15}{|l|}{1} \\
\hline \multicolumn{15}{|l|}{2} \\
\hline \multicolumn{15}{|l|}{$\ldots$} \\
\hline $\mathrm{N}$ & $\begin{array}{l}\text { Granting rights to } \\
\text { use or alienate } \\
\text { rights to protected } \\
\text { results of intellec- } \\
\text { tual activity, in- } \\
\text { cluding: }\end{array}$ & & & & & & & & & & & & & \\
\hline & & & & & & & & & & & & & & \\
\hline & & & & & & & & & & & & & & \\
\hline
\end{tabular}

2 Achievement of the planned values of the indicator of the effectiveness of the implementation

of a complex project in terms of the volume of manufactured high-tech products

\begin{tabular}{|c|c|c|c|c|c|c|c|c|c|c|c|c|c|c|c|c|c|c|}
\hline \multirow[b]{3}{*}{ Indicator name } & \multicolumn{9}{|c|}{ Planned } & \multicolumn{9}{|c|}{ Achieved } \\
\hline & \multirow[b]{2}{*}{ 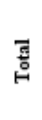 } & \multicolumn{8}{|c|}{ Including: } & \multirow[b]{2}{*}{ 횸 } & \multicolumn{8}{|c|}{ Including: } \\
\hline & & $\begin{array}{l}m \\
\stackrel{0}{0} \\
\text { 总 }\end{array}$ & 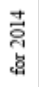 & 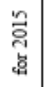 & 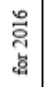 & $\begin{array}{l}\text { 范 } \\
\text { 蒐 }\end{array}$ & $\begin{array}{l}\infty \\
\overrightarrow{0} \\
\tilde{c} \\
\tilde{c}\end{array}$ & $\begin{array}{l}\text { 产 } \\
\text { 莒 }\end{array}$ & 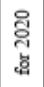 & & 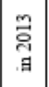 & $\begin{array}{l}\text { 苟 } \\
\text { 园 }\end{array}$ & 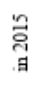 & $\begin{array}{l}\text { 号 } \\
\text { 晋 }\end{array}$ & $\begin{array}{l}\tilde{\mathrm{I}} \\
\text { 日 }\end{array}$ & $\begin{array}{l}\text { 节 } \\
\text { 目 }\end{array}$ & $\begin{array}{l}\text { वे } \\
\text { वे } \\
\text { a }\end{array}$ & 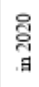 \\
\hline $\begin{array}{l}\text { The volume of new and improved high-tech products (services), pro- } \\
\text { duced using the results of R\&D, million rubles. }\end{array}$ & & & & & & & & & & & & & & & & & & \\
\hline
\end{tabular}

Figure 4. Current form of a high-tech product planned for release, created (developed) as part of an integrated project and its volumes.

Among the tools for management monitoring of the commercialization of high-tech projects, developed during this study, reporting Form 1.5 was improved, provided by the recipient of the Ministry of Education and Science at the stage of submitting the tender documentation with the filled-in information fields under item 1 , and at the stage of signing the agreement on the provision of the subsidy with added information on paragraph 2. It is proposed that this document is one of the clauses of the agreement (in terms of planned performance indicators, such as number of scientific publications, patent applications or activities carried out) or an annex to an agreement. A modernized and improved form of a high-tech product planned for release, created (developed) as part of an integrated project and its volumes, is shown in the Figure 5. 
REPORT

about the high-tech products planned for release, created (developed) within the framework of an integrated project and its volumes

Agreement with the Ministry of Education and Science of Russia from « " $\quad 201 \quad$ №

1 Volumes of manufactured high-tech products

\begin{tabular}{|c|c|c|c|c|c|c|c|c|c|}
\hline \multirow{3}{*}{ Ne } & \multirow{3}{*}{$\begin{array}{l}\text { Product name (new } \\
\text { and improved } \\
\text { high-tech products / } \\
\text { technology) }\end{array}$} & \multirow{3}{*}{$\begin{array}{c}\text { Name and } \\
\text { location of the } \\
\text { manufacturing } \\
\text { company }\end{array}$} & \multirow{3}{*}{$\begin{array}{l}\text { Document desig- } \\
\text { nation (No. TC or } \\
\text { set of design } \\
\text { (technological) } \\
\text { documentation) }\end{array}$} & \multicolumn{6}{|c|}{ Delivery contract } \\
\hline & & & & \multicolumn{3}{|c|}{ Buyer's brand name, country } & \multirow{2}{*}{$\begin{array}{l}\text { Number of } \\
\text { delivery units }\end{array}$} & \multirow{2}{*}{$\begin{array}{c}\text { Number of } \\
\text { products } \\
\text { (batch size) }\end{array}$} & \multirow{2}{*}{$\begin{array}{l}\text { Number of } \\
\text { delivery units }\end{array}$} \\
\hline & & & & $\begin{array}{c}\text { Domestic } \\
\text { market }\end{array}$ & $\begin{array}{c}\text { CIS } \\
\text { countries }\end{array}$ & $\begin{array}{l}\text { Other foreign } \\
\text { countries }\end{array}$ & & & \\
\hline 1 & & & & & & & & & \\
\hline 2 & & & & & & & & & \\
\hline$\ldots$ & & & & & & & & & \\
\hline $\mathrm{N}$ & $\begin{array}{l}\text { Granting rights to use or } \\
\text { alienate rights to pro- } \\
\text { tected results of intellec- } \\
\text { tual activity, including: }\end{array}$ & & & & & & & & \\
\hline & & & & & & & & & \\
\hline & & & & & & & & & \\
\hline & & & & & & & & & \\
\hline
\end{tabular}

2 Achievement of the planned values of the indicator of the effectiveness of the implementation of a complex project in terms of the volume of manufactured high-tech products

\begin{tabular}{|c|c|c|c|c|c|c|c|c|c|c|c|c|c|c|c|c|c|c|}
\hline \multirow[b]{3}{*}{ Indicator name } & \multicolumn{9}{|c|}{ Planned } & \multicolumn{9}{|c|}{ Achieved } \\
\hline & \multirow[b]{2}{*}{ ङूँّํ } & \multicolumn{8}{|c|}{ Including: } & \multicolumn{9}{|c|}{ Including: } \\
\hline & & $\begin{array}{l}m \\
\text { 空 } \\
\text { 岁 }\end{array}$ & 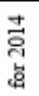 & 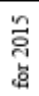 & 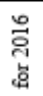 & 总 & $\begin{array}{l}\infty \\
\stackrel{\infty}{1} \\
\text { 芯 }\end{array}$ & 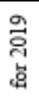 & 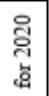 & ङूँّㅁ & 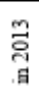 & 蒿 & 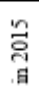 & 总 & 䒿 & 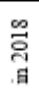 & 兽 & 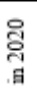 \\
\hline $\begin{array}{l}\text { The volume of new and improved high-tech } \\
\text { products (services), produced using the results of } \\
\text { R\&D, million rubles. }\end{array}$ & & & & & & & & & & & & & & & & & & \\
\hline
\end{tabular}

Figure 5. Modernized and improved form of a high-tech product planned for release, created (developed) as part of an integrated project and its volumes

From these tables it can be seen that the recipient of the subsidy here already undertakes to fulfill the plan in a certain established volume of output.

In 2018, the Ministry of Education and Science developed and signed an additional agreement

Table 1.

Existing applicable penalties. with the addition of a clause on the amount of penalties in case of non-fulfillment or lag in meeting performance indicators. The existing applicable penalties are shown in the Table 1 .
Number of publications resulting from the project in scientific journals indexed in Scopus database or in Web of Science database

Share of researchers under the age of 39 in the total number of researchers participating in the project

\author{
Amount of penalties \\ Return of the subsidy in the amount determined in proportion to the \\ ratio of the difference between the planned and actually achieved \\ performance indicator to the planned indicator. The formula for \\ calculating the return of the subsidy:

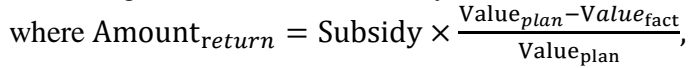 \\ Subsidy is the amount of the subsidy provided to the Subsidy \\ Recipient in the relevant year; \\ is the amount of the subsidy returned;Amount ${ }_{\text {return }}$ \\ is the sum of the planned values of performance indicators Value plan \\ in the corresponding year; \\ is the sum of the performance indicators actually achieved Value fact $_{\text {f }}$ \\ by the Recipient in the relevant year \\ Refund of the subsidy in the amount of $10 \%$ of the amount of the \\ subsidy provided to the Recipient of the subsidy in the corresponding \\ year
}


Volume of attracted extrabudgetary funds

Number of theses for scientific degrees defended based on the results of research and development

Number of events to demonstrate and popularize the results and achievements of science, in which the organization is the executing of the project took part and presented the results of the project

Number of patent applications based on research and development

Return of the subsidy in the amount of the difference between the planned and actually attracted in the corresponding year amount of extra-budgetary funds

Refund of the subsidy in the amount of $10 \%$ of the amount of the subsidy provided to the Recipient of the subsidy in the corresponding year

Refund of the subsidy in the amount of $10 \%$ of the amount of the subsidy provided to the Recipient of the subsidy in the corresponding year

Return of the subsidy in the amount determined in proportion to the ratio of the difference between the planned and actually achieved performance indicator to the planned indicator. The formula for calculating the return of the subsidy:

whereAmount $_{\text {return }}=$ Subsidy $\times \frac{\text { Value }_{\text {plan }}-\text { Value }_{\text {fact }}}{\text { Value }_{\text {plan }}}$,

Subsidy is the amount of the subsidy provided to the Subsidy

Recipient in the relevant year;

is the amount of the subsidy returned;Amount ${ }_{\text {return }}$

is the sum of the planned values of performance indicators Value $_{\text {plan }}$ in the corresponding year;

is the sum of the performance indicators actually achieved Value fact $_{\text {f }}$ by the Recipient in the relevant year

In this study, it is proposed to add to the performance indicator the volume of output, that is, the commercialization of the result obtained within five years after the end of the contract or agreement and, as a consequence of nonfulfillment or delay in implementation, the imposition of penalties in proportion to the amount of the subsidy received and the volume of production planned for five years. This change in the clause of the contract will ensure the fulfillment of the planned indicators for commercialization and will allow achieving the expected economic efficiency.

When testing the toolkit for management monitoring of the commercialization of high-tech projects developed within the framework of the study, a number of activities were carried out within the framework of one of Moscow Aviation Institute departments, SC SRESM. In 2016-2018, two projects have been successfully implemented on the basis of the department within the framework of Resolution № 218 and FTP. A marketing study was carried out, the task of which was to determine a strategy for the commercialization of scientific and technical products created using the results of work on the topic "Creation of a scientific and technical groundwork in the field of building a unified miniature airborne radar target load of small UAS vehicles for monitoring ice conditions during construction and operation of oil and gas platforms".

The complex of technical solutions developed in the course of the work, will make it possible to create a standard-size range of Russian smallsized and lightweight multi-band synthetic aperture radar systems.

Accordingly, the results obtained during the implementation of the project can find a fairly wide field for commercialization in the form of various products, services in the field of using UAS equipped with radar systems. The formation of a strategy for the commercialization of the results of work and created products in various market niches and segments, as applied to the branches of the real sector of the economy, was the main goal of the marketing research.

The main tasks were:

1. clarification of the most promising niches and market segments, as well as the volumes of the selected segments;

2. formation of a business model and strategy for bringing new products to the market.

In Russia, according to experts of the Aeronet Association, against the background of sanctions restrictions and the associated slowdown in economic growth, expressed in the development of the crisis, the market for unmanned aerial systems (UAS) and related technologies is growing annually by $15-20 \%$.

Based on the assessment of the most promising areas of commercialization, the following market niches were market niches for the newly created technical solutions within the framework of the work: 


\section{AMAZONIA \\ 10vestiga}

1. In the field of liquidation and prevention of emergencies:

1.1. search for people, vehicles, objects;

1.2. coordination of rescue operations at night and in conditions of limited visibility;

1.3. detection and control of extinguishing forest fires;

1.4. coordination of actions of rescue services in case of floods;

1.5. carrying out rescue operations at sea.

2. In the field of safety and security:

2.1. protection of state borders;

2.2. protection of the boundaries of objects and people;

2.3. detection of vehicles, objects and people, including those camouflaged or in conditions of poor visibility.

3. In the field of monitoring linear and areal objects:

3.1. nuclear, thermal and hydroelectric power plants (nuclear power plants, thermal power plants, hydroelectric power plants);

3.2. main power lines (power transmission lines);

3.3. land resources and real estate objects (cartography and cadastre);

3.4. oil and gas pipelines and other pipeline infrastructure facilities;

3.5. forest and water resources;
3.6. roads, railway lines and other transport facilities;

3.7. deposits, objects of the oil and gas and mining industries;

3.8. objects of agriculture.

4. In the field of geodesy, cartography and geophysics:

4.1. geo-calculator (calculating the volumes of embankments and mine workings);

4.2. geodetic works;

4.3. cartographic work;

4.4. geophysical work.

5. In the field of scientific research:

5.1. research in the Arctic, including ice exploration, snow cover research, etc.;

5.2. formation of accurate $3 \mathrm{D}$ terrain models;

5.3. equipment testing;

5.4. carrying out research and development in the field of creating radar systems.

The listed niches almost completely correspond to the main market niches in which the use of small UAS is effective, the total market size for which for the Russian market is shown in row 1 of Table 2. Foreign markets at the time of preparation of this study are not considered as achievable in connection with the sanctions policy of a number of Western states, limiting the possibility of entering them with "dual" products.

Table 2.

Forecast of sales of the developed product.

\begin{tabular}{|c|c|c|c|c|}
\hline Indicator name & 2018 & 2019 & 2020 & 2021 \\
\hline $\begin{array}{l}\text { Assessment of the volume of the Russian civilian segment of the } \\
\text { market for "tactical" UAV in physical terms (approximate number } \\
\text { of objects produced, in total in the Russian Federation), complex }\end{array}$ & 2000 & 3000 & 6500 & 13000 \\
\hline $\begin{array}{l}\text { Industrial partner market share (conservative estimate of market } \\
\text { share), \% }\end{array}$ & 2,5 & 2,5 & 2,5 & 2,5 \\
\hline $\begin{array}{l}\text { Share of the new product on the market of the total market volume } \\
\text { (as a part of industrial partner share), \% }\end{array}$ & test & 0,1 & 0,25 & 0,5 \\
\hline New product sales forecast (conservative estimate) & - & $2-3$ & $12-15$ & $50-60$ \\
\hline
\end{tabular}

As a part of the study, a number of activities were carried out:

- feasibility study was developed for the creation of high-tech production in order to rationalize the values of the project for the development of a priority direction of development, science and technology in the Russian Federation, in which the project is being implemented;

- brief analysis of the development of the market for UAS equipped with radar equipment was carried out;

- $\quad$ there are places in the market of companies that implement competing technologies;
- technical description of the products created for the commercialization of the results of the work was carried out;

- $\quad$ key competitive advantages of the products being developed were identified;

- positioning of the product in key market niches and segments was carried out.

\section{Results}

Based on the study, it can be concluded that the main way of communicating the results of work to consumers is to license the results of industrial partner project and organize the serial production of UAS by the latter. The industrial partner plans to communicate to the consumer information about new products created using the results 
through active sales and participation in industry events. The company also plans to take an active part in industrial events, where it will inform potential Customers about the features of the products being developed. In addition, independent commercialization will consist, first of all, in organizing the production of small-sized radar systems for their installation on UAV of various manufacturers. It is also possible that such a production will become a joint venture between the project contractor and the industrial partner.

Already in 2019, one contract has been signed for the modernization of an existing development, negotiations are underway on the installation of the developed radar system on UAV and helicopters:

- implementation of the results of the study is economically feasible due to the size of the expected average annual economic effect, the payback of the implementation of the development comes no later than a calendar year from the start of this implementation;

- size of the expected economic effect is changing over time and depends on a number of parameters.

\section{Conclusions}

Based on the data on the current state of implementation of high-tech projects, the factors influencing the prospects for the development of commercialization of both final product and its components are identified. If the course of preparation of tender documentation changes before the conclusion of contracts or agreements, the influence of negative factors can be avoided or at least reduced. For example, it was concluded that if there is a commercialization strategy and plan, information about the qualifications and resources of industrial partner and a written marketing research report agreed by both parties: the recipient of the subsidy and the industrial partner, it is possible to increase the level of commercialization of the product already at the initial stages.

The reasons and prerequisites for non-fulfillment of performance indicators for projects implemented in the high-tech production market are described in detail. The fundamental feasibility of introducing special innovations in terms of developing tools for management monitoring of the commercialization of high-tech projects was revealed. Innovations take place due to the magnitude of the expected average annual economic effect and the return on investment of the development, which occurs no later than a calendar year from the start of this implementation. This can only happen if there is a clear plan and obligations to the Ministry of Education and Science, which must be formalized in writing using the improved and modernized Form 1.5, as well as by introducing a new clause in the contract or agreement on the amount of penalties for non-fulfillment or lagging behind planned targets.

Requirements for a specialized mechanism of management control have been formulated and conceptual principles of its functioning have been determined. The mechanism should include a specific plan for the volume of products produced, should identify specific interested parties-buyers, and should also be limited in time to avoid penalties.

Measures have been developed to modernize the existing commercialization tools in priority areas of development: conducting marketing research before the conclusion of an agreement or agreement, developing a plan and strategy for commercialization, drawing up a specific plan for the volume of products for the next five years after expiration and system of penalties, carrying out activities to promote results.

The developed toolkit was tested on the example of a specific scientific and technical project to substantiate its practical feasibility and effectiveness, namely in SC SRESM on Resolution № 218 and FTP projects implemented in 2016-2018.

The expected economic efficiency of the implementation of the developed management monitoring toolkit for the main categories of persons who have objective and subjective interests was estimated. The state receives the spent budgetary funds through taxes and fees during the commercialization of the results of work, and the performers receive income from the conclusion of supply contracts.

Based on the foregoing, the scientific and scientific-applied results obtained in the course of the study represent the scientific solution proposed by the author to the urgent economic problem of developing tools for management monitoring of the commercialization of high-tech projects.

The organizational and economic mechanism developed in the scientific aspect has a particularly important scientific, economic and 


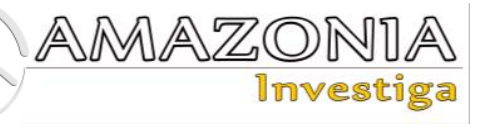

social significance in modern conditions and in the near future.

\section{References}

Arsenieva, N.V., Putyatina, L.M., \& Tarasova, N.V. (2020). Methodological Aspects of a Comprehensive Analysis of the Fixed Capital of Machine Building Enterprises. Economies, 8(3), 73.

Audretsch, D.B., \& Belitski, M. (2020). The role of R\&D and knowledge spillovers in innovation and productivity. European Economic Review, 123, 103391.

Beilin, I.L., Khomenko, V.V., Yakupova, N.M., Kadochnikova, E.I., \& Aleeva, D.D. (2019). Modeling of economic effects of commercialization of high-tech developments at small innovative enterprises of polymer profile. Revista TURISMO: Estudos e Práticas, 2, 1-9.

Burdina, A.A., \& Bondarenko, A.V. (2020). Assessing the strategic efficiency of aviation projects. Russian Engineering Research, 40, 439441.

Chaika, N. (2021). Formation of Development Strategy for Industrial Enterprise. Quality-Access to Success, 22(180), 20-26.

Chaika, N.K. (2019). The agreement granting the use of exclusive rights as a tool to recover creation costs. IOP Conference Series: Materials Science and Engineering, 537(4), 042058.

Dmitriev, O.N. (2020). Methodology for Estimating of Adequacy Concerning Mathematical Models of Complex Objects. TEM Journal, 9(3), 1021-1031.

Dmitriev, O.N., \& Novikov, S.V. (2021). Simulation in Managing an Enterprise's Stock of Equipment and Parts. Russian Engineering Research, 41(1), 76-78.

Dubitskaya, E., \& Tcukanova, O. (2018). Analysis of the influence of external environmental factors on the development of high-tech enterprises. MATEC Web of Conferences, 170, 01027.

Gbadegeshin, S.A. (2019). The effect of digitalization on the commercialization process of high-Technology companies in the life sciences industry. Technology Innovation Management Review, 9(1), 49-63.

Lastochkina, V.V., \& Savilova, N.V. (2020). State Regulation of Investment and the Development of High-Tech Enterprises. Russian Engineering Research, 40(12), 1118-1120.

Ling, J. (2020). The Transformation Efficiency and Influencing Factors of High-Tech Enterprises' Technological Achievements. Open Journal of Business and Management, 8(2), 696-712.

Novikov, S., Komarova, N., \& Dadyan, K. (2019). Development of a motivation system and supporting the success of the internal and external interactions of the network project group.
Amazonia Investiga, 8(20), 200-209. Retrieved from

https://amazoniainvestiga.info/index.php/amazonia /article/view/79

Pinkovetskaia, I.S., Arbeláez-Campillo, D.F., Rojas-Bahamón, M.J., Novikov, S.V., \& Veas Iniesta, D.S. (2020a). Social values of entrepreneurship in modern countries. Amazonia Investiga, $\quad 9(28), \quad 6-13$. https://amazoniainvestiga.info/index.php/amazonia /article/view/1276

Pinkovetskaia, I.S., Arbeláez-Campillo, D.F., Rojas-Bahamón, M.J., \& Veas Iniesta, D.S. (2020b). Motivation of new entrepreneurs in modern economies. Amazonia Investiga, 9(29), 368-373.

https://amazoniainvestiga.info/index.php/amazonia /article/view/1403

Putyatina, L.M., Tikhonov, G.V., Lavrova, L.A., \& Arsenyeva, N.V. (2020). Questions for Improving the Quality of Machine-Building Enterprises Workforce Management in Post-Crisis Conditions. TEM Journal, 9(4), 1543-1549.

Resolution of the Government of the Russian Federation № 426. "On the federal target program" Research and development in priority areas of development of the scientific and technological complex of Russia for 2014-2021" of May 21, 2013 $\mathrm{N} 426 . \quad$ Available at: https://base.garant.ru/70385450/

Resolution of the Government of the Russian Federation № 218. "On the approval of the Rules for the provision of subsidies for the development of cooperation of Russian educational institutions of higher education, state scientific institutions and organizations of the real sector of the economy in order to implement complex projects to create hightech industries and the Regulation on holding a competition to determine recipients of subsidies from the federal budget for the development of cooperation of Russian educational organizations higher education, state scientific institutions and organizations of the real sector of the economy in order to implement complex projects to create hightech industries" of April 9, 2010. Available at: https://base.garant.ru/12174931/

Tikhonov, A., \& Zelentsova, L. (2021). Analysis of External and Internal Factors of Business Competitiveness. Quality-Access to Success, 22(182), 16-19.

Tikhonov, G.V. (2021). Main approaches to the development of mechanical engineering as an echelon of economic dynamics. Journal of Physics: Conference Series, 1889(3), 032004.

Verevka, T. (2018). Key performance indicators of high-tech enterprises. SHS Web of Conferences, 44, p. 00077.

Ziyadin, S., Omarova, A., Doszhan, R., Saparova, G., \& Zharaskyzy, G. (2018). Diversification of R\&D results commercialization. Problems and perspectives in management, 16(4), 331-343. 